\title{
Do LDE-Methotrexate lipid nanoparticles decrease allograft vasculopathy in rabbit transplanted heart?
}

\author{
N Stolf ${ }^{* *}$, A Fiorelli', D Lorenço ${ }^{1}$, L Barbieri² ${ }^{1}$ E Tavares ${ }^{1}$, R Maranhão $^{1}$ \\ From 23rd World Congress of the World Society of Cardio-Thoracic Surgeons \\ Split, Croatia. 12-15 September 2013
}

\section{Background}

Cardiac allograft vasculopathy is the major fator limiting long term survival after heart transplantion. In a previus study we have shown that LDE binded with placitaxel decreases graft vasculopathy disease in rabbits. The objective of this study is to investigate the influence of LDE-Methotrexate nanoparticle in development of vasculopathy in rabbits tranplanted heart and expression profiles of cellular receptors, inflammatory mediators and metalloproteinases.

\section{Methods}

Heterotopic heart transplantation in cervical region was performed in twenty white male rabbits divided in two groups:

1. LDE-Metotrexate group: 10 rabbits treated with intravenous methotrexate particle once a week.

2. Control group: 10 rabbits treated with $3 \mathrm{ml}$ of intravenous saline solution once a week.

All animals were fed with food with $0.5 \%$ of cholesterol and receveid $10 \mathrm{mg} / \mathrm{kg} /$ day of cyclosporine. After six weeks of observation, the animals were sacrificed.

\section{Results}

Inflammation evaluated by macrophage distribution was reduced in animals treated with metotrexate from $27.1 \%$ to $6.0 \%(p=0.0020)$, compared to control group. Stenosis of coronary arteries had threefold decrease $(\mathrm{p}=0.0010)$ in LDE-Methotrexate group.

Values of relative gene expression profiles of Low density lipoprotein receptor; Low density lipoprotein receptor - related protein 1; IL-18; TNF $\alpha$; VCAM1 (Vascular cell

\footnotetext{
* Correspondence: nstolf@cardiol.br

${ }^{1}$ Cardiovascular Surgery, HCFMUSP-INCOR São Paulo, Brazil

Full list of author information is available at the end of the article
}

adhesion molecule-1) ; MCP-1 (Monocyte chemotactic protein-1) and MMP-12 (Matrix metalloproteinase 12 ) were significantly reduced $(\mathrm{p}<0.05)$ in methotrexate group.

\section{Conclusion}

Intravenous methotrexate with nanoparticules of LDEMethotrexate reduced allograft vasculopathy in transplanted hearts and inflamation markers.

\section{Authors' details}

${ }^{1}$ Cardiovascular Surgery, HCFMUSP-INCOR São Paulo, Brazil. ${ }^{2}$ Cardiovascular Surgery, Beneficencia Portuguesa São Paulo, Brazil.

Published: 11 September 2013

doi:10.1186/1749-8090-8-S1-0149

Cite this article as: Stolf et al:: Do LDE-Methotrexate lipid nanoparticles decrease allograft vasculopathy in rabbit transplanted heart ? Journal of Cardiothoracic Surgery 2013 8(Suppl 1):0149.

Submit your next manuscript to BioMed Central and take full advantage of:

- Convenient online submission

- Thorough peer review

- No space constraints or color figure charges

- Immediate publication on acceptance

- Inclusion in PubMed, CAS, Scopus and Google Scholar

- Research which is freely available for redistribution

Submit your manuscript at www.biomedcentral.com/submit 